\section{Chestnut Honey as a Complementary Medicine: Determination of Antibacterial Activity, Heavy Metal} Residue and Health Risk Assessment
Research Article

Mesut Ertan GÜNEŞ

Department of Food

Processing, Vocational

School of Technical

Science, Bursa Uludağ

University Turkey

ORCID-

$\underline{0000-0002-9347-8307}$

Correspondence

Mesut Ertan GÜNEŞ

egunes@uludag.edu.tr

Chestnut honey produced in Turkey is rich in bioactive substances (Küçük et al., 2007). Chestnut honey forests are located across Black Sea, Marmara and Aegean regions (Sarıaya et al., 2009). With its dark color and strong aromatic flavor chestnut honey is rich in glucose oxidase, catalase, ascorbic acid, carotenoid derivatives, organic acids, Maillard reaction products, amino acids and proteins, phenolic compounds, flavonoids and minerals such as tannin, potassium, magnesium, manganese and barium (Dağ et al., 2017). In different studies conducted on Anatolian chestnut honey, significant antioxidant compounds with high antibacterial activity are reported (Ayvaz et al., 2018; Güneş et al, 2017; Sarıkaya et al., 2019).

Honeybees are exposed to environmental pollutant as they gather plant nectar, pollen and water (De Oliveira et al. 2016). Bee products are important not only for their rich nutritional value but also together with the bees for being significant agents in monitoring environmental pollution (Yarsan et al., 2007).

\section{How to cite this article}

Güneş, ME. (2021). Chestnut Honey as a Complementary Medicine: Determination of Antibacterial Activity, Heavy Metal Residue and Health Risk Assessment. Journal of Advances in VetBio Science and Techniques, 6(2), 82-89. https://doi.org/10.31797/vetbio.931144
e-ISSN: 2548-1150

doi prefix: $10.31797 /$ vetbio

- http://dergipark.org.tr/vetbio

This work is licensed under a Creative Commons Attribution 4.0 International License (c) $(\mathrm{i}$ 
Metals such as arsenic, cadmium, lead and mercury may be present in soil, water and atmosphere at certain levels. In addition, metals may contaminate food products as a result of pollution by human activities such as vehicle exhaust, industrial waste, or irresponsible farming. Individuals may be exposed to such heavy metals through the environment, consumption of contaminated products and/or water. Accumulation of metals in the body may, in time, lead to several health issues and risks (Tolgahan et al., 2018).

In this study, residue levels for heavy metal content and antimicrobial effects of 27 chestnut honey samples obtained in 2014 from member beekeepers of Yalova Bee Association are examined.

\section{MATERIAL and METHOD}

\section{Honey samples}

Locations where honey samples are collected: 27 raw honey samples are collected from 7 different spots where the bee yards of Yalova Beekeepers Association members are commonly located. The collected samples are stored in glass jars in a dark and cool environment. All 27 samples are assessed in terms of their heavy metal profiles. Although no crystallization was expected for chestnut honey, 8 of the 27 samples were crystallized, therefore antibacterial activity is tested for the 19 non-crystallized honey samples.

\section{Antimicrobial analysis}

In this study, antibacterial activity is assessed on strains of S. aureus (ATCC 25923), E. coli (ATCC 25922), E. coli O 157: H7, B.cereus (ATCC 6633), S.Typhimirium (NCTC 12416) and L.monocytogenes (ATCC 7644). Agar-well diffusion method was used to assess antibacterial activity (Perez et al.,1990). Standard strains enriched in Mueller Hinton Broth are adjusted to 0.5 McFarland and cultivated into $1 \mathrm{ml}$. Mueller Hinton agar (Oxoid, CM 0337). Samples with a concentration of $100 \%, 50 \%(\mathrm{v} / \mathrm{v})$ and $25 \%(\mathrm{v} / \mathrm{v})$ are prepared from all 19 honey samples. Parallel honey samples of $50 \mu 1$ at each concentration level are added into holes with a diameter of 6 $\mathrm{mm}$ on the Petri dish. Plates are incubated at $37^{\circ} \mathrm{C}$ for 24 hours. The average of the inhibition zone diameters formed at the end of the incubation period is recorded. Zone diameters of $<5.5-9 \mathrm{~mm}, 9-12 \mathrm{~mm}, 12-15 \mathrm{~mm}$ and $>15$ $\mathrm{mm}$ indicate very low, low, average and high inhibition respectively (Küçük et al., 2007). All analyses are carried out two times as parallel processes.

\section{Heavy metal analysis}

Crystallized honey samples are kept in a water

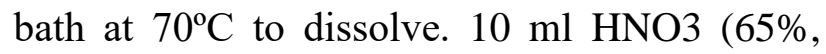
Merck) and $1 \mathrm{ml} \mathrm{H} 2 \mathrm{O} 2$ (30\%, Merck) are added on samples of $0.5 \mathrm{gr}$ and resulting samples are burned in a microwave oven (Berghof MWS-3+ / Germany) with gradually increasing temperature (160-200 C/max. $53 \mathrm{~min})$. At the end of the combustion, $5 \mathrm{ml}$ of ultrapure water (18.3 M $\Omega$ ultrapure water - Human, Korea) was added to each sample. Then, the concentrations of $\mathrm{Pb}, \mathrm{Cd}, \mathrm{As}$ and $\mathrm{Hg}$ are determined with a calibrated Plasma Optical Emission Spectrometer (ICP-OES-Perkin Elmer Optima 2100DV). Heavy metal analyses are conducted in the Food Research laboratory of Turkish Ministry of Agriculture and Forestry. The settings of the ICP-OES device are presented in Table 1.

\section{Potential health risk assessment of the honey samples}

Health risk of honey samples collected from Yalova province is determined by Target Hazard Quotient (THQ) analysis. THQ indicates the ratio between heavy metal exposure and the reference exposure dose. The potential health risk resulting from a daily consumption of $3.3 \mathrm{~g}$ (FAO, 2017) of honey is calculated for a seventy-year-old adult weighing seventy $\mathrm{kg}$ (Magna et al., 2018). 
Tablo 1. Operating Conditions of the ICP-OES (Perkin Elmer Optima 2100 DV).

\begin{tabular}{|c|c|}
\hline Parameter & \\
\hline RF power & 1450 watts \\
\hline Plasma gas flow & $15 \mathrm{~L} / \mathrm{min}$ \\
\hline Auxillary gas flow & $0.2 \mathrm{~L} / \mathrm{min}$ \\
\hline Nebulizer Flow & $0.65 \mathrm{~L} / \mathrm{min}$ \\
\hline Sample Pump Flow & $1.5 \mathrm{~mL} / \mathrm{min}$ \\
\hline Plasma Viewing & Dual View \\
\hline Elements & Wavelenth (nm) \\
\hline $\mathrm{Pb}$ & 220.353 \\
\hline $\mathrm{Cd}$ & 228.802 \\
\hline $\mathrm{As}$ & 193.696 \\
\hline $\mathrm{Hg}$ & 253.652 \\
\hline
\end{tabular}

$$
T H Q=\left[\frac{(E F r \cdot \text { EDtot } \cdot I F R \cdot C)}{(\text { RfDo } \cdot \text { BWa } \cdot \text { ATn })}\right] \cdot 10^{-3}
$$

Formula variables are as follows; EFr, indicates the exposure frequency $(365$ days/year); EDtot, the exposure duration (70 year); IFR, the food ingestion rate (g day-1); C, the concentration ( $\mu \mathrm{g} g-1$ ); RfDo, the oral reference dose $(\mu \mathrm{g}$ g-1 day- 1$)(\mathrm{Cd}: \mathrm{s} 0.001 ; \mathrm{Pb}$ : 0.004; As: 0.003 , day-1, $\mathrm{Hg}: 0,0016 \mathrm{mg} / \mathrm{kg}-$ 1/day declared by US-EPA, 2009; BWa, the adult body weight $(70 \mathrm{~kg})$ and $\mathrm{ATn}$, is the average time for non-carcinogens which is equal to EFr multiplied by EDtot.

\section{RESULTS}

Antibacterial effects on selected $\mathrm{Gr}(-)$ and $\mathrm{Gr}$ $(+)$ bacteria are presented in Table 2 . None of the 19 honey samples show antibacterial effect on strains of L. monocytogenes.

Tablo 2. Heavy Metal Levels of Honey Samples $(\mu \mathrm{g} / \mathrm{kg}$ ), Health Risk due to intake (THQ) and tolerable daily intake limits (\% PTDI)

\begin{tabular}{|ccccc|}
\hline$\mu \mathrm{g} / \mathrm{kg}$ & $\mathrm{Pb}(\mathrm{ppb})$ & $\mathrm{Cd}(\mathrm{ppb})$ & As $(\mathrm{ppb})$ & $\mathrm{Hg}(\mathrm{ppb})$ \\
\hline Lowest & 0.096 & 0.076 & 0.032 & 0.240 \\
\hline Highest & 39.067 & 1.198 & 0.950 & 44.546 \\
\hline Average & 21.301 & 1.183 & 0.516 & 21.490 \\
\hline Measurement uncertainty & \pm 0.004 & \pm 0.001 & \pm 0.001 & \pm 0.003 \\
\hline THQ & $2.5 \times 10^{-4}$ & $5.56 \times 10^{-5}$ & $8.1 \times 10^{-5}$ & $6.45 \times 10^{-4}$ \\
\hline PTDI (\%) & 4.4 & 15.4 & 4.71 & 4.4 \\
\hline
\end{tabular}

One hundred percent concentrations of all honey samples are recorded to have high antibacterial activity with wide zone diameters on strains of S. Typhimirium. Except for one sample, at $100 \%$ concentration level, all samples show antibacterial effect on strains of E. coli and B. cereus. Nevertheless, only 15 samples form antibacterial effect zones on S. aureus strains.
The antibacterial activity of samples at 50\% concentration level is found to be in line with that of $100 \%$ concentration. However, partial decreases in activity zones are recorded. When the concentration of honey samples is reduced to $25 \%$, a decline and even loss of antibacterial activity has been detected in many samples. At this concentration level, 8 samples are observed 
to show no antibacterial effect on S. Typhimirium strains while only 10 samples achieve to form activity zones on $\mathrm{S}$. aureus and E. coli O 157:H7 strains. The number of samples with activity zones at $25 \%$ concentration decreases to 7 samples on E. coli (ATCC 25922) and 3 samples on B.cereus strains. At all concentration levels, the highest antibacterial activity is detected on strains of S. Typhimirium. This is followed by E. coli O 157: H7 and E. coli, S. aureus and B. cereus, respectively.

Levels of Lead ( $\mathrm{Pb})$, Cadmium (Cd), Arsenic (As), Mercury $(\mathrm{Hg})$ in honey samples are determined by ICP-MS. Heavy metal contents of samples are recorded as $\overline{\mathrm{x}} 21.301348 \mathrm{ppb}$ for $\mathrm{Pb}$, $\overline{\mathrm{x}} 1.18381 \mathrm{ppb}$ for $\mathrm{Cd}, \overline{\mathrm{x}} 21.4909 \mathrm{ppb}$ for $\mathrm{Hg}$ and $\overline{\mathrm{x}} 0.51687 \mathrm{ppb}$ for As (Table 3).
When the potential health risk associated with heavy metal residue levels in Yalova chestnut honey samples are examined, exposure values are determined to be $2.5 \times 10-4$ for $\mathrm{Pb}, 5.5 \times 10$ 5 for $\mathrm{Cd}, 8.1 \times 10-5$ for As and 6.45 x 10-4 for $\mathrm{Hg}$. It is noted that the recorded levels are below the designated reference limits of daily consumption. (US-EPA 2009) Daily tolerable level of heavy metal intake (PTDI) determined by European Food Safety Authority (EFSA2012) and FAO/WHO Expert Committee on Food Additives (JEFCA 2011) are 0.357; 2.1; $0.185 ; 0.357 \mathrm{mg} / \mathrm{kg} /$ day for $\mathrm{Cd}$, $\mathrm{As}, \mathrm{Hg}, \mathrm{Pb}$ respectively. Taking these limits in consideration, a $70 \mathrm{~kg}$ adult's $3.3 \mathrm{gr}$ of Yalova honey consumption per day corresponds to $\% 15.4 \mathrm{Cd}>\% 4.7 \mathrm{As}>\% 4.4 \mathrm{~Pb}>\% 4.3 \mathrm{Hg}$ of the daily tolerable intake limits per each heavy metal. (Table 3)

Tablo 3. Heavy Metal Profiles of Yalova Honey and Samples in Previous Literature $(\mathrm{mg} / \mathrm{kg})$

\begin{tabular}{|c|c|c|c|c|c|}
\hline Origin of Samples & $\mathbf{P b}(\mathbf{p p m})$ & Cd (ppm) & As (ppm) & Hg (ppm) & Literature \\
\hline Yalova & 0.021 & 0.0011 & 0.0005 & 0.0214 & Our values \\
\hline Anatolia & 0.0003 & 0.000038 & & & Altunatmaz, 2018 \\
\hline Tokat & 0.0018 & 0.000041 & & & Arıkan, 2010 \\
\hline Elazı $\breve{g}$ & 0,409 & 337.9 & 4.8 & & Aygün, 2020 \\
\hline Bingöl & $\mathrm{Nd}$ & nd & nd & nd & Bengü, 2020 \\
\hline Trakya & Bdl- 0,48 & Bdl-0,01 & & & Citak, 2012 \\
\hline Mid-Anatolia & 1.5 & 0.242 & & & Leblebici, 2008 \\
\hline China & 0.033 & 0.001 & 0.013 & 0.0016 & Mei-ru, 2013 \\
\hline Sicily & 0.170 & 0.0153 & & & Naccari, 2014 \\
\hline Karadeniz & $0.04-0.73$ & nd- 1.28 & & & Nisbet, 2013 \\
\hline Muğla & $0.005-0.016$ & Bdl & & & Silici, 2013 \\
\hline Comercial & 1.101 & 0.343 & & 0.618 & Şireli,2015 \\
\hline Anatolian & $0.008-0.106$ & $0.9-17.9$ & & & Tuzen, 2007 \\
\hline Hatay & 0.39 & 0.03 & & & Yücel, 2013 \\
\hline
\end{tabular}

\section{DISCUSSION}

It was first suggested in 1892 by Van Ketel et al. (1892) that honey may have antibacterial effects (Dustman, 1979). The antibacterial activity of honey was first described in 1937, by Duo and Dziao (1937) and the substance in honey enabling for bacteria inhibition was named as inhibin. It is later argued that the antibacterial efficacy may also be influenced by the floral sources from which the honey is obtained (Molan et al., 1988).

In a study focusing on honey samples from Turkey, the antimicrobial activity of chestnut, rhododendron, and multifloral honey samples is examined against the strains of Helicobacter pylori, S. aureus, B. subtilis, C. tropicalis and C. albicans and the highest antimicrobial activity is 
recorded for chestnut honey (Küçük et al., 2007). Results of the studies referring to a correlation between the antibacterial activity of chestnut honey and its antioxidant capacity have shown that the types of honey with high antioxidant content, especially chestnut honey, also exhibit significantly high antibacterial efficacy (Ayvaz et al., 2018; Güneş et al., 2016; Yıldız et al., 2013).

S.aureus is the most vulnerable and sensitive bacteria against the antibacterial effect of honey. Güneş et. al. (2017) recorded antibacterial activity of chestnut honey at 100\%, 50\% and $25 \%$ concentrations on strains of S.aureus. In this study, strong antibacterial activity against $\mathrm{S}$. aureus strains is determined for chestnut honey samples from Yalova province.

Ayvaz et al. (2018) reported that the most sensitive microorganisms to chestnut honey samples from the Black Sea region are C. albicans, S. aureus and E. coli, while the most resistant microorganism is B. subtilis. The antibacterial activity of honey samples from Yalova province on E. coli strains is in line with this study. Combarros-Fuertes et al. (2020) investigated the chestnut, avocado and polyfloral honey samples' mechanism of action on E. coli and S. aureus strains and pointed out that all honey types caused significant alterations on the cell structures of E. coli and S. aureus. The study especially highlighted the remarkable metabolic deformations caused on S. aureus by honey samples' antibacterial effect.

In their studies on chestnut honey and its antibacterial and antifungal activity on strains of E. coli ATCC (25922), Yersinia pseudotuberculosis ATCC (911), Pseudomonas aeruginosa ATCC (43288), S. aureus, ATCC (25923), Enterococcus faecalis ATCC (29212), B. cereus (709 Roma), Mycobacterium smegmatis (ATCC607), Candida albicans ATCC (60.193) and Saccharomyces cerevisiae (RSKK 251), Kolayli et al. (2016) recorded the highest inhibition levels against $\mathrm{S}$. aureus, E. faecalis, Y. pseudotuberculosis and E. coli strains.

The antimicrobial properties of honey are due to its acidity, osmolarity, $\mathrm{H}_{2} \mathrm{O}_{2}$, low water activity (aW), aromatic acids, different chemical compounds; phenolics and flavonoids content (Bogdanov et al., 2008). Chestnut honey is rich in terms of mineral content and phenolic compounds (Güneş et al., 2017; Kolaylı et al., 2016). The highest antibacterial activity for honey samples from Yalova province is observed on S.Typhimirium followed by E. coli O 157:H7 and E.coli, S.aureus and B.cereus, respectively. Studies have shown that chestnut honey accelerates the treatment of wound infections and, especially, shortens the healing process of open wounds caused by diabetes (McLoone et al., 2020). The therapeutic efficacy of Yalova chestnut honey should be considered and utilized for the same purpose.

Heavy metals such as lead, cadmium, arsenic and mercury are taken into the human body through food products, drinking water and respiration. Such metals cannot be excreted through the body's excretory system and accumulate in the soft tissues of the body. Accumulation of each metal at levels above the effective doses for children and adults may cause organ poisoning, and several other severe health issues (i.e. thyroid, neurological, autism and infertility) and even death (Özpolat, 2016).

Yalova province is surrounded by the regions where heavy industrial organizations operate. In the study, pollution levels and potential health risks are revealed by the heavy metal profiles of honey samples obtained from the region.

The average lead level of 27 honey samples analyzed in the study is found to be $0.021 \mathrm{ppm}$. This is below the levels recorded in all previous studies mentioned above. (Table 4) However, the lead levels of honey samples from Yalova are found to be above the levels recorded by Tuzen et al. (2007) for honey samples from different cities in Anatolia, Arıkan (2010) for samples 
from Tokat province, Silici and et al. (2013) for samples from Muğla, Nisbet et al. (2013) for samples from Black Sea region, Altunalmaz et al. (2018) for samples from Anatolia and Bengü (2011) for samples from Bingöl province.

Tablo 4. Antimicrobial Activity of Chestnut Honey from Yalova

\begin{tabular}{|c|c|c|c|c|c|c|c|c|c|c|c|c|c|c|c|c|c|c|c|c|}
\hline \multirow{2}{*}{$\begin{array}{c}\text { Con. } \\
\text { v/v } \\
(\%)\end{array}$} & \multirow[t]{2}{*}{ Bacteria } & \multicolumn{19}{|c|}{ Honey Samples (Inhibition zone diameter mm) } \\
\hline & & 1 & 2 & 3 & 4 & 5 & 6 & 7 & 8 & 9 & 10 & 11 & 12 & 13 & 14 & 15 & 16 & 17 & 18 & 19 \\
\hline \multirow{5}{*}{$100 \%$} & B.cereus & 27 & 28 & 27 & 31 & 26 & 29 & 26 & - & 28 & 29 & 30 & 32 & 28 & 27 & 27 & 29 & 26 & 30 & 33 \\
\hline & S.aureus & 20 & - & 15 & 21 & 18 & - & - & - & 14 & 15 & 17 & 15 & 13 & 15 & 15 & 19 & 18 & 14 & 14 \\
\hline & E.coli & 29 & 29 & 28 & 33 & 32 & 30 & - & 30 & 32 & 31 & 35 & 33 & 30 & 31 & 34 & 30 & 31 & 31 & 32 \\
\hline & E.coli O157 H:7 & 29 & 33 & 30 & - & 32 & 28 & 29 & 26 & 30 & 30 & 30 & 32 & 31 & 30 & 31 & 31 & 30 & 32 & 32 \\
\hline & S. Typhimirium & 30 & 32 & 30 & 38 & 30 & 28 & 36 & 41 & 32 & 34 & 32 & 36 & 36 & 40 & 35 & 32 & 28 & 38 & 32 \\
\hline \multirow{5}{*}{$50 \%$} & B.cereus & 23 & 24 & 19 & - & 20 & 23 & 23 & - & 24 & 26 & 24 & 25 & 26 & 22 & 19 & 25 & - & 24 & 24 \\
\hline & S.aureus & 12 & - & 13 & 14 & 14 & - & - & - & 11 & 13 & 14 & 11 & - & 14 & - & 14 & 15 & 12 & 11 \\
\hline & E.coli & 25 & 24 & 26 & 28 & 20 & 24 & - & 22 & 27 & 23 & 29 & 24 & 24 & 22 & 27 & 28 & 29 & 24 & 27 \\
\hline & E.coli O157 H:7 & 26 & 23 & 27 & - & 25 & 27 & 27 & 22 & 27 & 25 & 23 & 28 & 28 & 27 & 28 & 23 & 26 & 29 & 26 \\
\hline & S. Typhimirium & 23 & 18 & 22 & 26 & 20 & 19 & 18 & 21 & 23 & 20 & 20 & 18 & 23 & 24 & 19 & 22 & 22 & 20 & 27 \\
\hline \multirow{5}{*}{$25 \%$} & B.cereus & 15 & - & - & - & 14 & - & - & - & - & - & - & 20 & - & - & - & - & - & - & - \\
\hline & S.aureus & 10 & - & 10 & 12 & 11 & - & - & - & - & 11 & 11 & - & - & - & - & 12 & 11 & 9 & - \\
\hline & E.coli & 22 & - & - & 24 & - & 19 & & 20 & - & 19 & - & 19 & - & - & - & - & - & 19 & - \\
\hline & E.coli O157 H:7 & 22 & - & 24 & - & - & 22 & - & 18 & 23 & - & 16 & - & - & 15 & - & - & 19 & 23 & - \\
\hline & S. Typhimirium & 18 & 17 & 19 & 22 & 18 & - & - & 19 & 22 & - & 17 & - & - & - & - & 18 & 18 & 16 & - \\
\hline
\end{tabular}

The average cadmium level of honey samples from Yalova is recorded to be $0.0011 \mathrm{ppm}$. Considering the previous literature, a higher cadmium level is observed compared to honey samples collected from Tokat (Arikan, 2010), Trakya (sunflower honey samples) (Çıtak, 2012), Muğla (Silici, 2013), Anatolian region Altunazmaz, 2018) and Bingöl (Bengü, 2020). Compared to the previously published studies, lower cadmium levels are observed. In a study conducted by Naccari et al.(2016) on 3 different monofloral honey samples in Sicily, higher lead and cadmium levels were recorded compared to the present stud

The average arsenic residue levels for honey samples collected from Yalova is determined to be $0,0005 \mathrm{ppm}$. This is a lower level compared to honey samples for Elazığ (Aygün, 2020).

In the study, the average mercury residue level of 30 chestnut honey samples is found to be $0.0214 \mathrm{ppm}$. The observed level is much lower compared to the residue limits recorded by Şireli et al. (2015) for commercial honey samples. The mercury residue level obtained by $\mathrm{Ru}$ et al. (2013) in their study on 48 monofloral honey samples is lower than that of Yalova honey. The cadmium values recorded in the same study are similar to the findings of this study while the lead and arsenic levels are higher than the values observed for chestnut honey samples from Yalova.

There is no designated maximum limit on the heavy metal contamination of honey in the Turkish Food Codex Regulation (TGK29.12.2011). It is concluded that the target hazard quotient and health risk factors associated with lead, cadmium, arsenic and mercury residues in honey calculated for a seventy-yearold adult, weighing seventy $\mathrm{kg}$ with a $3.3 \mathrm{~g}$ of daily honey consumption, is below the reference limits set by US-EPA (US-EPA 2009). When the level of heavy metal residues in the honey samples are evaluated for consumer health and in 
terms of tolerable weekly intake limits (EFSA 2012, JEFCA 2011), it is determined that a $70 \mathrm{~kg}$ adult's 3.3 gr of Yalova honey consumption per day corresponds to $15.4 \%, 4.7 \%, 4.4 \%, 4.3 \%$ of the daily tolerable intake limit for $\mathrm{Cd}, \mathrm{As}, \mathrm{Pb}$, $\mathrm{Hg}$, respectively. Adjusting for individual differences, potential health risk factors associated with a daily consumption of even 15 $\mathrm{g}$ of honey collected from Yalova province would be below the designated reference limits.

\section{CONCLUSION}

In conclusion, pure chestnut honey has a potential to be a complementary product in protective and therapeutic applications for human health. It has been concluded that honey samples obtained from Yalova region is a valuable source in terms of their potential use in treatments of both traditional and complementary medicine (apitherapy). period.

\section{ACKNOWLEDGMENT}

The authors kindly thank Dr. Evren Erköse and appreciate his contributions during the research

Ethical approval: It has been declared that it is not subject to ethics committee approval.

Conflict of interest: The authors declare that they have no conflict of interest.

\section{KAYNAKLAR}

Altunatmaz, S.S., Tarhan, D., Aksu, F., Özsobacı, N.P, Erman, M., \& Barutçu, U.M. (2018). Levels of Chromium, Copper, Iron, Magnesium, Manganese, Selenium, Zinc, Cadmium, Lead and Aluminium of honey varieties produced in Turkey. Food Science and Technology, 39, 392-397. Doi:10.1590/fst.19718

Arıkan A. (2010). The effect of traffic on heavy metal accumulation in bee products. Ms Thesis, Gaziosmanpasa University,Graduate School of Natural and Applied Sciences, Tokat.

Aygün, O. (2020). Elazığ'da Üretilen Balların Bazı Toksik Ağır Metal Düzeyleri. Firat Üniversitesi Mühendislik Bilimleri Dergisi, 32(1), 119-125.

Ayvaz, M. Ç., Ömür, B., Ertürk, Ö., \& Kabakçı, D. (2018). Phenolic profiles, antioxidant, antimicr obial, and DNA damageinhibitory activities of chestnut honeys from Black Sea Regionof Turkey. Journal of Food Biochemistry 42:e12502
Bengü, A.Ş., \& Kutlu, M.A. (2020). Bingöl'den temin edilen ballarda $1 \mathrm{cp}$-ms ile bazı temel ve toksik elementlerin analizi. Uludă̆ Arıcılık Dergisi, 20 (1), 112.

Bogdanov, S., Jurendic, RS., Sieber, R., \& Gallmann, P. (2008). Honey for Nutrition and Health: A Review. Journal of the American College of Nutrition, 27 (6), 677-689.

Citak, D., Silici, S., Tuzen, M., \& Soylak, M. (2012). Determination of toxic and essential elements in sunflower honeyfrom Thrace Region, Turkey. International Journal of Food Science and Technology, 47, 107-113. Doi:10.1111/j.13652621.2011.02814.x

Combarros-Fuertes, P., Estevinho, L.M., TeixeiraSantos, R., Rodrigues, A.G., Pina-Vaz, C., Fresno, J.M., \& Eugenia Tornadijo, M. (2020). Antibacterial Action Mechanisms of Honey: Physiological Effects of Avocado, Chestnut,and Polyfloral Honey upon Staphylococcus aureus and Escherichia coli. Molecules, 25, 1252. Doi:10.3390/molecules25051252

Dağ, B., Sıralı, R., \& Tarakçı, Z. (2017). Investigation of Some Properties of Chestnut Honey Produced in Black Sea Region of Turkey. Batman University Journal of Life Sciences, 7(2/2), 118-123.

De Oliveira, R.C., Queiroz, S.C.D.N., Da Luz, C.F.P., Porto, R.S., \& Rath S. (2016). Bee pollen as a bioindicator of environmental pesticide contamination. Chemosphere, 163, 525-534. doi:10.1016/j.chemosphere.2016.08.022

Duo, D.H., \& Dziao, S.T. (1937). Nachweis antibakterieller, hitze- und lichtempfindlicher Hemmungsstoffe Inhibine im Naturhonig Blatenhonig. Zeitschrift far Hygiene und lnfektionskrankheiten, 120, 155-167.

Dustmann, J. H. (1979). Antibacterial effect of honey. Apiacta, 14(1), 7-11.

EFSA (2012) Scientific Committee. Scientific panels and units in theabsence of actual measured data. European Food Safety Authority Journal, 10: 2579. doi: 10.2903/j.efsa.2012.2579

FAO/WHO Expert Committee on Food Additives (JECFA) (2011). Safety evaluation of certain food additives and contaminants. WHO Food Additives. 63, 605-685.

F.A.O. (Food and Agriculture Organization of the United Nations) (2017). Largest consumers of honey. 1-2. $\quad 2020$ Oct.1http://www.fao.org/3/ca4657en/ca4657en.pdf.

Güneş, M. E., Şahin, S., Demir, C., Borum, E., \& Tosunoglu, A. (2017). Determination of phenolic compounds profile in chestnut and floralhoneys and their antioxidant and antimicrobial activities. Journal of Food Biochemistry, 41(3), 1-12.

Idris, Y. M. A., Mariod, A. A., \& Hamad, S. I. (2011). Physicochemical properties, phenolic contents and antioxidant activity of Sudanese honey. International Journal of Food Properties, 14, 450-458. 
Kolayli, S., Can, Z., Yildiz, O, Sahin, H., \& Karaoglu, S.A. (2016). A comparative study of the antihyaluronidase, antiurease, antioxidant, antimicrobial and physicochemical properties of different unifloral degrees of chestnut (Castanea sativa Mill.) honeys. Journal of Enzyme Inhibition and Medicinal Chemistry, 31(S3), 96-104. https://doi.org/10.1080/14756366.2016.1209494

Küçük, M; Kolaylı, S; Karaoğlu,Ş; Ulus,Y,E; Baltacı,C; \& Candan,F (2007). Biological activities and chemical composition of three honeys of different types from Anatolia. Food Chemistry, 100(2), 526-534

Leblebici, Z. (2006). Kayseri Yöresinde Bulunan Bazı Bal Örneklerinde Ağır Metal Kirliliğinin Belirlenmesi, Yüksek Lisans Tezi, Erciyes Üniversitesi Fen Bilimleri Enstitüsü, Kayseri, 71.

Magna, E.K., Dabi, M., Badu, E, \& Owusu, P. (2108). Determination of Heavy Metals and Potential Health Risk Assessment of Honey Harvested from the Tamale Metropolis of Ghana Using Atomic Absorption Spectrophotometer (AAS). Elixir Pollution, 121, 51522-51525.

McLoone, P., Tabys, D., \& Fyfe, L. (2020). Honey Combination Therapies for Skin and Wound Infections: A Systematic Review of the Literature. Clinical, Cosmetic and Investigational Dermatology, 13, 875-888. doi: 10.2147/CCID.S282143.

Molan, P.C., Smith, I.M., \& Reid, G.M. (1988). A comparison of the antibacterial activity of some New Zealand honeys. Journal of Apicultural Research, 27(4): 252-256.

Naccari, C., Macaluso, A., Giangrosso, G., Naccari, F., \& Ferrantelli, V. (2014). Risk Assessment of Heavy Metals and Pesticides in Honey from Sicily (Italy). Journal of Food Research, 3(2), 107-117. doi:10.5539/jfr.v3n2p107

Nisbet, C., Guler, A., Yarim, G.F., Cenesiz, S., \& Ardalı, Y. (2013). Çevre ve flora kaynaklarının arı ürünlerinin mineral madde içerikleri ile ilişkisi. Türk Biyokimya Dergisi, 38 (4), 494-498.

Özbolat, G., \& Tuli, A. (2016). Ağır metal toksisitesinin insan sağlığına etkileri. Archives Medical Review Journal, 25(4), 502-521. doi:10.17827/aktd.253562

Perez, C., Pauli, M., \& Bazerque, P. (1990). An antibiotic assay by the agar well diffusion method. Acta Biologia et Medicine Experimentalis, 15, 113-115.

Ru, Q.M., Feng, Q., \& He, H_J. (2013). Risk assessment of heavy metals in honey consumed in Zhejiang province, southeastern China. Food and Chemical Toxicology. 53: 256-262. https://doi.org/10.1016/j.fct.2012.12.015

Sarıkaya, A. O., Ulusoy, E., Ozturk, N., Tunçel, M., \& Kolayli, S. (2009). Activity and phenolic acidconstituents of chestnut (Castania sativamill.) honey and propolis. Journal of Food Biochemistry, 33, 470-481.

Seven, T., Can, B, Darende, B.N, \& Ocak, S. (2018), Hava ve Toprakta Ağır Metal Kirliliği. Ulusal Çevre Bilimleri Araştırma Dergisi, 1(2), 91-103.
Silici, S., Uluozlu, O.Z., Tuzen, M., \& Soylak, M. (2013). Honeybees and honey as monitors for heavy metal contamination near thermal power plants in Mugla, Turkey. Toxicology and Industrial Health, 32(3), 507-516. DOI: 10.1177/0748233713503393

Şireli, U.T., Çil, G.İ., Dikmen, B.Y, Filazi, A., \& Ülker, H. (2015). Detection of Metals in Different Honey Brands. Kafkas Universitesi Veteriner Fakültesi Dergisi, 21(6), 915-918.

Tuzen, M., Silici, S., Mendil, D., \& Soylak, M. (2007). Trace element levels in honeys from different regions of Turkey. Food Chemistry, 103, 325-330. Doi:10.1016/j.foodchem.2006.07.053

Türk Gıda Kodeksi Bulaşanlar Yönetmeliği (2011). Resmi Gazete, 29.12.2011, Sayı: 28157 (3. Mükerrer), Ankara

USEPA. (2009). Risk-based Concentration table. Philadelphia PA. Washington DC, USA,Environmental Protection Agency

Yarsan, E., Karacal, F., Ibrahim, I.G., Dikmen, B., Koksal, A., \& Das, Y.K. (2007). Contents of Some Metals in Honeys from Different Regions in Turkey. Bulletin of Environmental Contamination and Toxicology,79, 255-258. DOI: 10.1007/s00128-0079034-9

Yıldız, O., Can, A., Saral, O., Yuluğ, E., Ozturk, F., Aliyazicioglu, R., Canpolat, S., \& Kolayli, S. (2013). Hepatoprotective potential of chestnut bee pollen on carbon tetrachloride-induced hepatic damages in rats. Journal of Evidence Based Complementary and Alternative Medicine, Special Issue, Article ID 461478, 9 p. http://dx.doi.org/10.1155/2013/461478

Yücel, Y., \& Sultanoğlu, P. (2013). Characterization of Hatay honeys according to their multi-element analysis using ICP-OES combined with chemometrics. Food Chemistry, 140, 231-237. https://doi.org/10.1016/j.foodchem.2013.02.046 